\title{
Incision Wound Healing Test of Ethanolic Extract Gel from Salaon (Parsonsia alboflavescens [Dennst.] Mabb.) Leaves in Male Rats
}

\author{
Nilsya Zebua*(D), Muharni Saputri, Winda Giovana Sijabat, Inda Aristika Sri Retno Wulandari, Ira Nofriani, Winda Agustiani Zai, \\ Ramadani Arda Arista, Muhammad Suhaimi, Aula Firsa
}

Department of Pharmacy, Faculty of Pharmacy, Tjut Nyak Dhien University, Sumatera Utara, Indonesia

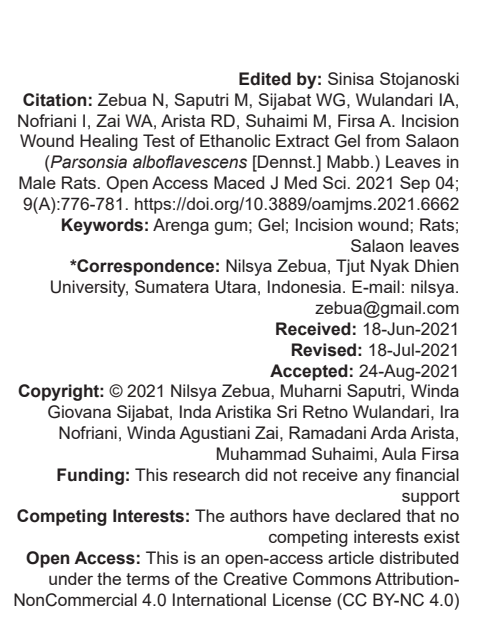

Introduction

A wound is an end result of a bodily harm that reasons harm and penetrates into the layers of the skin [1]. The basic principle of top-rated wound healing is to minimize tissue damage and provide good enough tissue perfusion and oxygenation, the right nutrients, and a moist wound healing environment to restore the anatomical continuity and characteristic of the affected part [2].

Research on natural ingredients on substances that may accelerate wound healing is one among the items that are presently developing and is being tried by researchers and ancient practitioners around the world. The use of treatments with natural ingredients is becoming increasingly popular today because it has fewer side effects than conventional preparations [3]. The time course of healing for an acute wound usually ranges from 5 to 10 days, or within 30 days [4]

One of the plants that can be used as traditional medicine is salaon (Parsonsia alboflavescens [Dennst.] Mabb.) leaves. Salaon is derived from the Apocynaceae family. Empirically salaon leaves have been used to treat bruises, gastric wounds, as well as open wounds. In conventional medication inside the Asia Pacific region, the species Apocynaceae is used to deal with fever, malaria, pain, diabetes, and gastrointestinal diseases [5].

In general, the preparation of wound drugs in the form of liquid or semi-solid form. Half-solid dosage forms such as ointments, creams, and gels are options for all the better ones including longer drug contact and protecting wounds from extraordinary diagnostic. The dosage form of the gel is easier to use and the spread on the skin is faster. In addition, the gel has cooling, moisturizing properties, and easily penetrates the skin to provide a healing effect. Gel preparations can protect the skin from excessive dehydration. The formulation and selection of the right base on the manufacture of gels will affect the number and speed of the active substance to be absorbed. Ideally, the base and carrier should be easy to wear on the skin, not irritating, and safe to use on [6].

In this study, the base of the gel used is gum derived from Arenga pinnata. Gum has been widely used as a thickener, emulsion stabilizer as well as additive in various food and medicine industries. Gum is also known to have antimicrobial and antioxidant properties [7]. 


\section{Materials and Methods}

\section{Materials}

Salaon (P. alboflavescens [Dennst.] Mabb.) leaves, aquadest, Arenga pinnata, ethanol 96\% (v/v), ethanol $70 \%(\mathrm{v} / \mathrm{v})$, ethanol p.a $99.5 \%(\mathrm{v} / \mathrm{v})$, glycerol $99.5 \%$, lidocaine $2 \%$, methyl paraben, propylene glycol.

\section{Collection of materials}

The samples used are salaon leaves from Sidamanik Subdistrict, Simalungun Regency, North Sumatra, Indonesia, collected from December 2020 to January 2021.

\section{Making of simpliscia powder}

Salaon leaves are cleaned of dirt, then dried in a dryer cabinet with a temperature of $\pm 45^{\circ} \mathrm{C}$ then mashed with a blender and weighed the weight of dry powder.

\section{Arenga gum extraction}

Arenga gum was weighed then washed thoroughly with aqueducts and then smoothed with a ratio of 1:10 water. Once smooth, the sugar palm fruit is filtered with mesh 18 and then put in the refrigerator at $4^{\circ} \mathrm{C}$ for $24 \mathrm{~h}$. Then a cross-union of supernatant and ethanol $96 \%$ with a ratio of $1: 2$, after which it is stored in the refrigerator at $4^{\circ} \mathrm{C}$ for $24 \mathrm{~h}$. The formed sediment is filtered, then soaked in ethanol p.a $99.5 \%$ for $5 \mathrm{~min}$ then strain and squeeze until dry. Once dry is crushed until slightly smooth, put it in a container and store in the desiccator until dry [8].

\section{Basic gel formulation}

The basic formula of the standard gel contains $5 \mathrm{~g}$ Carboxymethyl cellulose- $\mathrm{Na}$ (CMC-Na), $10 \mathrm{~g}$ glycerol $5 \mathrm{~g}$, propylene glycol, and aqua dest till $100 \mathrm{ml}[9]$.

\section{Modification gel formulation}

The modified gel formula is made by replacing CMC-Na as thickener and gel shaper with arenga gum, the addition of extracts, and addition of methylparaben as preservatives with formula $5 \mathrm{~g}$ arenga pinnata, $10 \mathrm{~g}$ glycerol, $5 \mathrm{~g}$ propylene glycol, aqua dest till $100 \mathrm{ml}$, and salaon leaves extract with some concentration $(2.5 \%$, $5 \%$, and $7.5 \%$ ) (Table 1 ).

The material is weighed according to the weight of each formula. In beaker, glasses are filled with $100 \mathrm{ml}$ of aqua dest, and added arenga gum then homogenized using a magnetic stirrer on the hotplate until a homogeneous period is formed. Furthermore, methylparaben, glycerol, and propylene glycol are added so that a homogeneous gel base is obtained. After the base of the gel was homogeneous then added ethanol extract salaon leaves then homogenized.

\section{Gel evaluation}

Gel evaluation includes organoleptic, homogeneity test, $\mathrm{pH}$ test, cycling test, viscosity test, spread resistance test, and irritation test for volunteers.

\section{Organoleptic}

Gel inspection and description consist of an examination of form, color, and odor [10].

\section{Homogeneity}

All developed gels were tested for homogeneity by visual inspection. Its appearance and the presence of aggregates were tested [11], [12].

\section{Measurement of $\mathrm{pH}$}

The $\mathrm{pH}$ of the gel was measured by using a digital $\mathrm{pH}$ meter. Digital $\mathrm{pH}$ meter is dipped in a diluted gel sample, let stand for a while and the result is adjusted to the standard $\mathrm{pH}$ meter [13].

\section{Stability test}

Each formula is placed in a transparent glass container. The gel is stored at a temperature of $4 \pm 2^{\circ} \mathrm{C}$ for $24 \mathrm{~h}$, then transferred to an oven at $40^{\circ} \mathrm{C}$ for $24 \mathrm{~h}$ ( 1 cycle). Testing was conducted as many as six cycles or for 12 days and observed the occurrence or absence of changes that occur in each formula. Gel conditions compared during experiments with previous gel conditions.

Table 1: Modification gel formulation

\begin{tabular}{|c|c|c|c|c|}
\hline \multirow[t]{2}{*}{ Material } & \multicolumn{4}{|c|}{ Formula and composition } \\
\hline & Blanko & F1 & F2 & F3 \\
\hline Extract ethanol of salaon leaves & - & 2,5 & 5 & 7,5 \\
\hline Arenga gum $(\mathrm{g})$ & 5 & 5 & 5 & 5 \\
\hline Glycerol (g) & 10 & 10 & 10 & 10 \\
\hline Propylene glycol (g) & 5 & 5 & 5 & 5 \\
\hline Methyl paraben (g) & 0,1 & 0,1 & 0,1 & 0,1 \\
\hline Aquadest $(\mathrm{ml})$ & Till 100 & Till 100 & Till 100 & Till 100 \\
\hline
\end{tabular}

\section{Spreadability}

The gel is weighed as much as $0.5 \mathrm{~g}$ and then placed in the middle of a scaled round glass. On top of the gel is placed other round glass or other transparent materials and ballast so that the weight of the glass is round and ballast $150 \mathrm{~g}$, silenced $1 \mathrm{~min}$, then noted the diameter of its spread [14]. 
Table 2: Organoleptic gel test results

\begin{tabular}{llll}
\hline Formulation & Form & Color & Odor \\
\hline Blanko & Semi-solid & Peach & Arenga odor \\
Placenta extract gel & Semi-solid & White & Gel odor \\
F1 & Semi-solid & Black & Leaf odor \\
F2 & Semi-solid & Black & Leaf odor \\
F3 & Semi-solid & Black & Leaf odor \\
\hline
\end{tabular}

Table 3: Gel homogeneity test results

\begin{tabular}{ll}
\hline Formulation & Homogeneity \\
\hline Blanko & Homogeneous \\
Placenta extract gel & Homogeneous \\
F1 & Homogeneous \\
F2 & Homogeneous \\
F3 & Homogeneous \\
\hline
\end{tabular}

\section{Measurement of viscosity}

A total of $100 \mathrm{ml}$ of gel is put in a tube-shaped container and then installed spindle 4. Spindles should be submerged in test preparations. Viscometers are turned on and mounted rotors can rotate at a speed of $60 \mathrm{rpm}$.

\section{Irritation test}

The irritation test is done with a closed patch test in which the cream is applied to the inside of the arm, then covered with gauze, after $24 \mathrm{~h}$, watch for any symptoms. This trial was conducted on 25 female volunteers aged 18-25 years, with the condition: Healthy woman, 18-25 years old, no history of allergy, participate voluntarily, healthy physically and mentally [15].

Table 4: $\mathrm{pH}$ gel test results

\begin{tabular}{lc}
\hline Formulation & $\mathrm{pH}$ value \\
\hline Blanko & 6.13 \\
Placenta extract gel & 6.13 \\
F1 & 6.12 \\
F2 & 6.12 \\
F3 & 5 \\
\hline
\end{tabular}

\section{Adhesion test}

The sample of $0.25 \mathrm{~g}$ aped between two glass objects and a load of $1 \mathrm{~kg}$ for $5 \mathrm{~min}$. The load is large and the load is $80 \mathrm{~g}$ on the appliance. The time at which the gel comes off the glass object.

\section{Preparation of experiment animal}

The FMIPA USU Animal Research Ethics Committee has approved the protocol study with Ethical clearance number 0151/KEPH-FMIPA/2021. The test animal used is a male rat. The test animals prepared were as many as 25 heads that were

\section{Table 5: Spreadability results}

\begin{tabular}{ll}
\hline Formulation & Spreadability $(\mathrm{cm})$ \\
\hline Blanko & 5 \\
Placenta extract gel & 5.1 \\
F1 & 5.2 \\
F2 & 53 \\
F3. & 6.6 \\
\hline
\end{tabular}

randomly divided into 5 groups of animals and then adapted to environmental conditions for 1 week. Criteria of test animals include age 2-3 months, male sex, weight $200 \mathrm{~g}$, a healthy condition characterized by active movement, rat food in the form of pellets and for beverages used bottles as much as $20-45 \mathrm{ml}$ per day and mice placed in one cage.

Table 6: Viscosity results

\begin{tabular}{ll}
\hline Formulation & Viscosity (dPa.s) \\
\hline Blanko & 99.9 \\
Placenta extract gel & 92.6 \\
F1 & 72 \\
F2 & 71.8 \\
F3 & 44.9 \\
\hline
\end{tabular}

\section{Incision wound healing test}

The hair around the area to be injured is shaved and cleaned using a $70 \%$ alcoholic cotton swab. The need is done after the previous rats were annexed using lidocaine. In the area is made an incision in the back area using scalpel along $1 \mathrm{~cm}$ to the subcutaneous layer.

Table 7: Irritation test results

\begin{tabular}{lll}
\hline Formulation & Volunteer & Symptoms \\
\hline Blanko & 1 & No symptoms \\
Blanko & 2 & No symptoms \\
Blanko & 3 & No symptoms \\
Blanko & 4 & No symptoms \\
Blanko & 5 & No symptoms \\
Placenta extract gel & 6 & No symptoms \\
Placenta extract gel & 7 & No symptoms \\
Placenta extract gel & 8 & No symptoms \\
Placenta extract gel & 9 & No symptoms \\
Placenta extract gel & 10 & No symptoms \\
F1 & 11 & No symptoms \\
F1 & 12 & No symptoms \\
F1 & 13 & No symptoms \\
F1 & 14 & No symptoms \\
F1 & 15 & No symptoms \\
F2 & 16 & No symptoms \\
F2 & 17 & No symptoms \\
F2 & 18 & No symptoms \\
F2 & 19 & No symptoms \\
F2 & 20 & No symptoms \\
F3 & 21 & No symptoms \\
F3 & 22 & No symptoms \\
F3 & 23 & No symptoms \\
F3 & 24 & No symptoms \\
F3 & 25 & No symptoms \\
\hline
\end{tabular}

A total of 25 male rats Wet divided into 5 groups, each group consisting of 5 heads. The rat group was given an ethanol extract gel of salaon leaves.

a. Group I: Negative control i.e. rats given gel base

b. Group II: Positive control i.e. mice given comparison gel.

c. Group III: Rats were given ethanol extract gel of salaon leaves concentration of $2.5 \%$

d. Group IV: Mice given were ethanol extract gel of salaon leaves concentration of $5 \%$

e. Group V: Mice were given ethanol extract gel of salaon leaves concentration of $7.5 \%$

In male rats that suffered cuts, the gel was thinly applied 1 (one) time a day (the wound was not closed). Observation of wounds is done every day visually by measuring the length of the wound until the wound is considered healed (the wound is dry and the length of the wound is reduced. 


\section{Data analysis}

Data collection and analysis were conducted based on the length of the cut and the time it took for the wound in mice to heal using a formulation of salaon leaf extract gel with different concentrations and gel comparison for the cuts on the market. Data analysis using SPSS 26.0 Free trial method one way Analysis of variance (ANOVA) and Post-Hoc Tukey Honest Significant Difference (HSD). Kruskal-Wallis tests are performed for normal non-distributed data.

\section{Results}

Incision wound healing test of ethanol extract gel of salaon leaves aims to know the presence of an effect on the decrease in the length of the wound and the percentage of wound healing. This test was conducted on male rat test animals. The cut wounds that have been made are then given therapy using salaon leaf ethanol extract gel according to the treatment group namely negative control group (gel base), positive control group (Placenta extract gel), F1 (concentration group $2.5 \%$ ), F2 (concentration group 5\%), and F3 (concentration group 7.5\%) (Tables 2-7).

Measurement of the length of the cut in all treatment groups is done visually from the first day to the eighth day. The average measurement of the length of the cut wounds of each group of male rats is shown in Tables 8-10.

Table 8: Adhesion test results

\begin{tabular}{ll}
\hline Formulation & Adhesion (s) \\
\hline Blanko & 25 \\
Placenta extract gel & 38 \\
F1 & 37 \\
F2 & 34 \\
F3 & 24 \\
\hline
\end{tabular}

\section{Discussion}

The results of the homogeneity test of the gel preparation showed that the entire gel formula has good homogeneity that does not contain any grain in a piece of glass. Flattened gel, if there are no granules in a piece of glass, it can be said that the preparation is homogeneous [16]. The results of experiments that have been conducted on gel preparations from salaon leaves ethanol extract there are no granules on a piece of glass, so the preparation is said to be homogeneous.

$\mathrm{pH}$ test results show all formulas have a $\mathrm{pH}$ that is close to the normal $\mathrm{pH}$ range of the skin so that all formulas can meet good and safe tropical preparation criteria if applied to damaged skin such as
Table 9: Average length of wound

\begin{tabular}{llllll}
\hline Days & \multicolumn{7}{l}{ Average length of wound $(\mathrm{cm})$} & & \\
\cline { 2 - 6 } & G1 & G2 & G3 & G4 & G5 \\
\hline 1 & 1 & 0.96 & 0.94 & 0.94 & 0.88 \\
2 & 0.98 & 0.92 & 0.9 & 0.84 & 0.82 \\
3 & 0.92 & 0.74 & 0.78 & 0.74 & 0.68 \\
4 & 0.84 & 0.62 & 0.64 & 0.56 & 0.68 \\
5 & 0.82 & 0.56 & 0,6 & 0.46 & 0,6 \\
6 & 0.74 & 0.4 & 0.54 & 0.26 & 0.54 \\
7 & 0.64 & 0.24 & 0.44 & 0.06 & 0.44 \\
8 & 0.54 & 0.06 & 0.42 & 0 & 0.28 \\
\hline
\end{tabular}

cuts. $\mathrm{pH}$ preparations that meet the $\mathrm{pH}$ criteria of the skin are in the range of 5-8 [17]. If the $\mathrm{pH}$ value of the composition preparation is too acidic, it will cause skin irritation, and if the $\mathrm{pH}$ value of the composition preparation is too alkaline, it will cause skin dryness and irritation [18].

Stability test results showed that all preparations were stable, with no discoloration and shape change after storage for six cycles. The results of the spread test showed that the spreadability of all gel preparation formulas tested was in the skin's spread range of 5.0 $7.0 \mathrm{~cm}$, so it can be concluded that the gel preparations meet the requirements of good gel spreadability [17]. The therapeutic effect of gels depends on their distribution. The distribution of gels contributes to the uniform application of gels on the skin. Therefore, the produced gels should have good distribution and ideal quality for topical application [19].

Table 10: Tukey honest significant difference day 8 post-hoc statistical analysis

\begin{tabular}{llllll}
\hline Treatment & $\mathrm{n}$ & \multicolumn{2}{l}{ Subset for alpha $=0.05$} & & \\
\cline { 3 - 6 } & & 1 & 2 & 3 & 4 \\
\hline Concentration 5\% & 5 & 0.00 & & & \\
Positive Control & 5 & 0.06 & 0.28 & & \\
Concentration 7.5\% & 5 & & & 0.42 & 0.54 \\
Concentration 2.5\% & 5 & & & & 1 \\
Negative Control & 5 & & 1 & 1 & 1 \\
Sig. & & 0.25 & 1 & \\
\hline
\end{tabular}

Irritant tests are performed on the skin to determine whether or not there are side effects of gel preparations. The formula is declared safe in case of no allergic reactions or irritations to the skin. Based on the results of the irritant test obtained showing the absence of allergic reactions and irritations caused by the preparations, it can be concluded that all formulas are safe to use.

The results of the adhesion test showed that the entire formula had an adhesion of more than $4 \mathrm{~s}$. Standard gel adhesiveness is not $<4 \mathrm{~s}$. The longer the gel's adhesion time the better because it allows the active substance to be fully eliminated. From the data obtained all formulas meet the standards of gel adhesiveness [20].

The results of the measurement of the length of the wound showed that there are differences in the wound healing process for each concentration. G1 is used as a negative control to prove whether ethanol extract of salaon leaves can be used as a medicine to accelerate the healing of wounds. From the data, when viewed from a therapeutic point of view, placenta extract gel, a gel containing $2.5 \%$ and $7.5 \%$ salaon leaves 


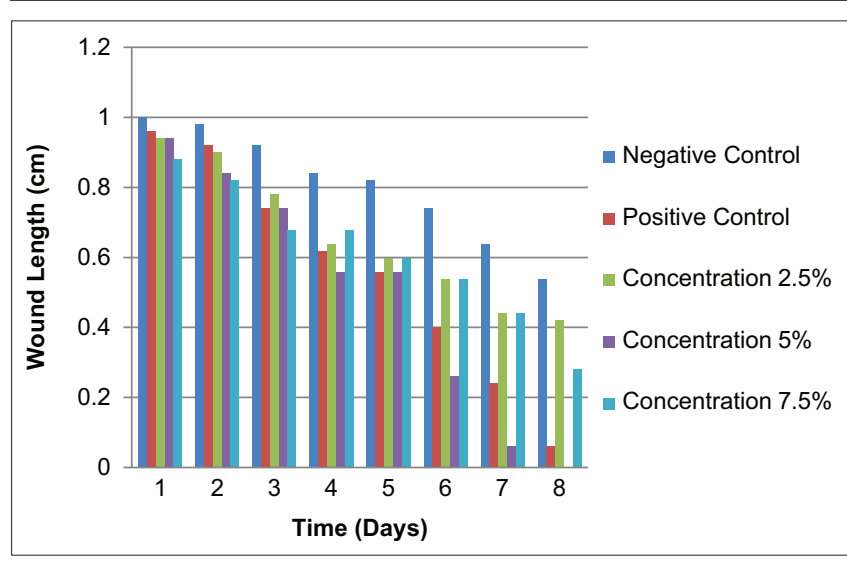

Figure 1: Wound length measurement graph

ethanol extract has less healing power compared to gels containing $5 \%$ salaon leaves ethanol extract. Then ethanol extract gel of salaon leaves $5 \%$ is the most effective to accelerate the healing of wounds (Figure 1).

The data of the measurement of the length of the incision wound obtained is then obtained statistically using SPSS 26.0 Free trial. Statistical analysis of the measurement data of the length of the incision wound includes formality test, One Way ANOVA test, Post-Hoc Tukey HSD test, and Kruskal-Wallis. Test normality data using the Shapiro-Wilk test. If the data is distributed normally, a homogeneity test is conducted with the Levene test. If the variance of normal and homogeneous distributed data is continued by the parametric test method, namely One Way ANOVA tests. When data are not distributed normally, a Kruskal-Wallis non-parametric test is used. Hypotheses are considered meaningful when the value $p<0.05$ if in the test ANOVA produced a value of $p<0.05$ then continued by conducting a Post Hoc Tuckey HSD analysis.

Based on the data that has been obtained, normally distributed data is data on the $3^{\text {rd }}, 4^{\text {th }}, 5^{\text {th }}, 6^{\text {th }}$, $7^{\text {th }}$, and $8^{\text {th }}$ days with $(p>0.05)$. The data meet the requirements of one way ANOVA test while for normal non-distributed data, data on the $1^{\text {st }}$ and $2^{\text {nd }}$ day are conducted Kruskal-Wallis test. Based on the results of the Kruskal-Wallis test found that broadly found a significant difference that is the value of $p>0.05$.

The results of the analysis of the measurement data of the length of the cut on the $8^{\text {th }}$ day obtained from the One Way ANOVA test showed a signification value of $p<0.05$ which is $p=0.000$, which means there is a meaningful difference in each treatment group. To find out there are significant differences in each treatment group followed by a Post-Hoc Tukey HSD test.

Based on the results of the Post Hoc Tuckey HSD test it is known that the length of the gel cut with a concentration of $5 \%$ does not differ significantly from the positive control of Placenta extract gel. Quantitative analysis of preparations containing ethanol extract of salaon leaves concentration is 5\% more effective compared to concentrations of $2.5 \%$ and $7 \%$ due to a faster decrease in the length of cuts.

\section{Conclusion}

All preparation formulas of gel extract ethanol leaves salaon meet the quality requirements of gel evaluation. The preparation of salaon leaf ethanol extract gel can heal wounds in male rats. Post-Hoc Tukey HSD test results obtained a concentration result of $5 \%$ not significantly different from Placenta extract gel as a positive control. The optimum dose of ethanol extract gel of salaon leaves that can cure incision wound in male rats in the dosage form of the gel is $5 \%$.

\section{References}

1. Ersel M, Uyanikgil Y, Akarca FK, Ozcete E, Altunci YA Karabey $F$, et al. Effects of silk Sericin on incision wound healing in a dorsal skin flap wound healing rat model. Med Sc Monit. 2016;22:1064-78. https://doi.org/10.12659/msm.897981 PMid:27032876

2. Gadekar R, Saurabh MK, Thakur GS, Saurabh A. Study of formulation, characterisation and wound healing potential of transdermal patches of curcumin. Asian J Pharm Clin Res. 2012;5(4):225-30.

3. Tabassum N, Ahmad F. Role of natural herbs in the treatment of hypertension. Pharmacogn Rev. 2011;5(9):30-40. https://doi. org/10.4103/0973-7847.79097

PMid:22096316

4. Velnar T, Bailey T, Smrkolj V. The wound healing process: An overview of the cellular and molecular mechanisms. J Int Med Res. 2009;37(5):1528-42. https://doi. org/10.1177/147323000903700531

PMid:19930861

5. Chan EW, Wong SK, Chan HT. Apocynaceae species with antiproliferative and/or antiplasmodial properties: A review of ten genera. J Integrat Med. 2016;14(4):269-84. https://doi. org/10.1016/s2095-4964(16)60261-3

PMid:27417173

6. Farid N, Awaluddin N, Hamzah S, Yusuf M, Rahmania R. Formulation and antibacterial activity test of hand sanitizer ethanol extract of basil (Ocimum Sanctum. L) against Escherichia coli and Streptococcus aureus. Med Kesehatan Politeknik Kesehatan Makassar. 2020;15(2):228-37. https://doi. org/10.32382/medkes.v15i2.1764

7. Sayuti K, Neswati N, Hijra R, Effendi E. Antioxidant activity of "Kolang Kaling" Jam which is added with "Pucuk Merah" (Syzygium oleana) fruit juice. Asian J Appl Res Community Dev Empowerment. 2020;4(1):28-33. https://doi.org/10.29165/ ajarcde.v4i1.36

8. Kaban J, Reveny J, Tarigan J, Zebua NF. Modificated extraction and purity test of Arenga pinnata Gum. Asian J Pharm Clin Res. 2018;11:148-50. https://doi.org/10.22159/ajpcr.2018.v11s1.26593

9. Maswadeh HM, Semreen MH, Naddaf AR. Anti-inflammatory activity of Achillea and Ruscus topical gel on carrageenaninduced paw edema in rats. Acta Pol Pharm. 2006;63(4):277-80. PMid:17203864

10. Leny L, Ginting EE, Hafiz I. Formulation and evaluation of candlenut (Aleurites moluccana L.) oil in gel preparation. Asian J Pharm Res Dev. 2020;8(5):41-3. https://doi.org/10.22270/ ajprd.v8i5.842 
11. Gupta R, Gupta DG. Formulation development and evaluation of ant-inflamantory potential of Cordia obliqua topical gel on animal model. Pharmacogn J. 2017;9(6):s93-8. https://doi. org/10.5530/pj.2017.6s.163

12. Saiesh P, Shabaraya AR, Shripathy D, Soman L. Formulation and evaluation of topical gel containing econazole nitrate. Int J Univ Pharm Bio Sci. 2014;3(3):82-91.

13. Febriyenti $F$, Putri RF, Suharti N. Formulation and evaluation of patchouli oil gel. J Sains Farmasi Klinis. 2019;6(3):191-4. https://doi.org/10.25077/jsfk.6.3.191-194.2019

14. Garg A, Aggarwal D, Garg S, Sigla AK. Spreading of semisolid formulation: An update. Pharm Tecnol. 2002;9(2):84-102.

15. Hasri NM, Zebua NF, Sudewi S. Test of burn wounds healing effects of collagen from snakehead fish (Channa striata) bone in the preparation of cream on male white rats (Rattus norvegicus). Indones J Pharm Clin Res. 2020;3(1):62-75. https://doi.org/10.32734/idjpcr.v3i1.3977

16. Nazliniwaty N, Karsono K, Zebua NF, Nerdy N. Antioxidant activity and antiaging gel formulation grapefruit peel (Citrus maxima Merr.) ethanolic extract. Der Pharm Lett. 2016;8(20):84-94.
17. Zebua NF, Putra ED, Harahap U, Kaban J. Durian seed utilization as a base material of tropical gel. Asian J Pharm Clin Res. 2018;11(1):174-7. https://doi.org/10.22159/ajpcr.2018. v11s1.26600

18. Arifin $B$, Nasution $R$, Desriani $N$, Marianne $M$, Helwati $H$. Antimikrobial activity of hand lotion of flower Mimusops elengi. Open Access Maced J Med Sci. 2019;7(22):3748-56. https:// doi.org/10.3889/oamjms.2019.496

PMid:32127968

19. Dantas MG, Reis SA, Damasceno CM, Rolim LA, RolimNeto PJ, Carvalho FO, et al. Development and evaluation of stability of a gel formulation containing the monoterpene borneol. ScientificWorldJournal. 2016;2016:7394685 https://doi. org/10.1155/2016/7394685

PMid:27247965

20. Lumentut N, Edi HJ, Rumondor EM. Formulasi dan uji stabilitas fisik sediaan krim ekstrak buah pisang goroho (Musa Acuminafe L.) konsentrasi $12.5 \%$ sebagai Tabir Surya. J MIPA. 2020;9(2):42-6. https://doi.org/10.35799/ jmuo.9.2.2020.28248 